\title{
USE OF EU FUNDS IN AREAS OF EDUCATION INEQUALITY. EXAMPLES OF MEASURES IN SELECTED THREE RURAL COMMUNES OF THE ŁÓDZKIE VOIVODSHIP IN 2006-2013
}

\author{
Ewa GABRYELAK • Elżbieta PSYK-PIOTROWSKA \\ Uniwersytet Łódzki \\ Katedra Socjologii Wsi i Miasta \\ ul Rewolucji 1905 r. 41, 90-214 Łódź \\ ewa.gabryelak@gmial.com•elapsyk@uni.lodz.pl
}

\begin{abstract}
Zarys treści: Celem artykułu jest przedstawienie wyników działań realizowanych w latach 2006-2013 w ramach projektów unijnych przez wybrane gminy z województwa łódzkiego na rzecz poprawy szans edukacyjnych dzieci i młodzieży z terenów wiejskich. Projekty wspierały przemiany w wybranych (i zdefiniowanych) obszarach nierówności w zakresie edukacji na wsi, począwszy od edukacji przedszkolnej poprzez wdrażanie programów w szkołach ogólnych oraz pozyskiwanie środków na programy doskonalenia nauczycieli. Dzięki funduszom unijnym możliwa jest realizacja kompleksowych działań wspierających istniejące placówki oświatowe oraz powoływanie nowych, doposażanie bazy dydaktycznej, w tym także tworzenie bogatej infrastruktury sportowej, zmianę kwalifikacji kadry pedagogicznej, jak również inwestycje w infrastrukturę edukacyjną. Punktem wyjścia są dane statystyczne dotyczące zrealizowanych w okresie 2006-2013 projektów w edukacji przy wykorzystaniu środków UE w województwie łódzkim. Następnie zaprezentowane są przykłady zrealizowanych projektów (z uwzględnieniem obszaru nierówności) w trzech gminach województwa łódzkiego: Drużbice z powiatu bełchatowskiego, Grabów z powiatu łęczyckiego i Kowiesy z powiatu skierniewickiego. Podstawowym materiałem są źródła zastane, pozyskane na szczeblu województwa oraz analizowanych gmin.
\end{abstract}

Słowa kluczowe: nierówności w edukacji, szanse edukacyjne, fundusze Unii Europejskiej, fundusze unijne, obszary wiejskie.

\section{Wprowadzenie}

Wspieranie rozwoju obszarów wiejskich dotyczy nie tylko w rolnictwa, które jest ciągle głównym źródłem utrzymania wielu mieszkańców wsi, ale również możliwości wykorzystania potencjału tych obszarów dla tworzenia nowych miejsc pracy i zatrudnienia poza 
rolnictwem. Jednym z narzędzi procesu przemian na obszarach wiejskich są fundusze zewnętrzne, przyspieszające, a często także umożliwiające proces transformacji. Należą do nich instrumenty Wspólnej Polityki Rolnej, w tym Europejskiego Funduszu Rolnego na rzecz Rozwoju Obszarów Wiejskich. Wspieranie pozarolniczego potencjału rozwojowego obszarów wiejskich możliwe jest także dzięki środkom i instrumentom polityki spójności. Zgodnie z zapisami Programu Rozwoju Obszarów Wiejskich na lata 2007-2013 działania te odnoszą się bezpośrednio do Wytycznej 2.2 Wspieranie zróżnicowania gospodarczego obszarów wiejskich, obszarów rybołówstwa oraz obszarów o niekorzystnym położeniu ze względu na warunki przyrodnicze.

W Polsce występują istotne różnice między regionami i wewnątrz nich. Szczególnie podkreślane są różnice rozwojowe pomiędzy miastem a wsią. Społeczeństwo obszarów wiejskich funkcjonuje w gorszych warunkach materialnych, a struktura jego dochodów jest często związana ze strukturą wiejskiego rynku pracy (Szafraniec 2012, s. 204-208, 211; Gorlach 2003, s. 27). Znaczący wpływ na tempo rozwoju obszarów wiejskich ma sytuacja gospodarcza oraz trudności w dostępie do infrastruktury społecznej, teleinformatycznej, edukacyjnej czy kulturalnej. Czynniki te mają także wpływ na wykształcenie i aspiracje edukacyjne dzieci i młodzieży wiejskiej. Młodzież wiejska, mimo zbliżonych do miejskiej osiągnięć na wcześniejszych etapach edukacji, często wybiera kształcenie na kierunkach tradycyjnych (jak np. pedagogika) oferowanych przez uczelnie prywatne, z dala od dużych ośrodków akademickich, co wpływa negatywnie na ich późniejsze możliwości znalezienia pracy (Kwiecińska-Zdrenka 2004, s. 110-122; Niezgoda 2011, s. 13-14; Szafraniec 2011, s. 94-96, 109-112; Herbst 2012b, s. 54-55, 113-115). W Strategii Rozwoju Edukacji na Obszarach Wiejskich na lata 2007-2013 podkreśla się, że dysproporcje pomiędzy miastem a wsią są bezpośrednimi barierami w dalszym rozwoju obszarów wiejskich, wpływają na mniejszą atrakcyjność tych obszarów. Szereg barier związanych z funkcjonowaniem systemu oświaty na terenach wiejskich ma bezpośredni wpływ na gorszy start i mniejsze szanse edukacyjne dzieci wiejskich, stąd konieczna jest poprawa warunków i możliwości ich edukacji.

Nierówności występujące w infrastrukturze technicznej, jak i sferze społecznej, skazują tereny wiejskie na marginalizację gospodarczą, społeczną, edukacyjną i kulturową. Dlatego polityka spójności skierowana jest na wyrównywanie szans rozwojowych na obszarach wiejskich, a zaplanowane w ramach Narodowych Strategicznych Ram Odniesienia (Narodowa Strategia Spójności... 2007, s.73-74) działania wspierają rozbudowę infrastruktury technicznej i społecznej, tworzenie warunków dla rozwoju przedsiębiorczości, w tym nowych miejsc pracy niezwiązanych z działalnością rolniczą, ochronę środowiska, edukację (w tym kształcenie ustawiczne), oraz tworzenie warunków lepszej dostępności do podstawowych usług, zwłaszcza w zakresie ochrony zdrowia. Zakłada się, że zmiany zachodzące dzięki absorpcji funduszy unijnych, będą wpływać na poprawę jakości życia mieszkańców, wyrównanie dysproporcji pomiędzy bogatszymi i biedniejszymi regionami oraz między miastem a wsią. Fundusze unijne ułatwiają niwelowanie nierówności w dostępie do edukacji dzieci wiejskich, pozwalając dofinansować programy lokalne, w tym także oddolne inicjatywy na terenach wiejskich.

Na podstawie analizy literatury przedmiotu, jak również danych statystycznych GUS, można wyróżnić następujące obszary nierówności dotyczących edukacji na wsi:

- dostępność edukacji na poziomie przedszkolnym,

- dostępność zajęć dodatkowych i wyrównawczych, 
- dostęp do poradnictwa psychologiczno-pedagogicznego i edukacyjnego dla najmłodszych dzieci,

- poziom kwalifikacji nauczycieli,

- infrastruktura edukacyjna na obszarach wiejskich. (por. m.in. Guz 2005, s. 73-85, 94-104; Dolata 2008; Herczyński 2012, s. 14-39).

Wyodrębnione obszary dotyczą usług edukacyjnych zagwarantowanych na poziomie gminy jako zadania własnego jednostek samorządu terytorialnego (JST), tj. edukacji przedszkolnej, szkół podstawowych i gimnazjum, odpowiadają także dostępnym źródłom środków zewnętrznych, w tym głównie środków funduszu spójności i funduszy strukturalnych Unii Europejskiej, dzięki którym możliwe jest wdrażanie nowych rozwiązań lub usprawnień wpływających na niwelowanie dysproporcji w zakresie edukacji. Możliwość pozyskiwania funduszy pozwala wspierać przemiany mające na celu rozwój edukacji na obszarach wiejskich, a także przeciwdziałanie negatywnym trendom występującym w wyodrębnionych obszarach.

Tabela 1. Fundusze UE i programy przeznaczone na cele edukacyjne

\begin{tabular}{|l|c|c|}
\hline \multicolumn{1}{|c|}{ Obszar wsparcia } & $\begin{array}{c}\text { Europejski Fundusz } \\
\text { Społeczny (EFS) }\end{array}$ & $\begin{array}{c}\text { Europejski Fundusz Roz- } \\
\text { woju Regionalnego (EFRR) }\end{array}$ \\
\hline 1/ Edukacja przedszkolna & SPO RZL ${ }^{1}$ PO KL ${ }^{2}$ & - \\
2/ Zajęcia wyrównawcze i koła zainteresowań & SPO RZL, PO KL & - \\
3/ Diagnoza i niwelowanie deficytów rozwojowych & SPO RZL, PO KL & - \\
4/ Doskonalenie nauczycieli i kadry pedagogicznej & SPO RZL, PO KL & - \\
5/ Poprawa infrastruktury edukacyjnej & - & ZPORR $^{3}, \mathrm{RPO} \mathrm{Wt}^{4}$ \\
\hline
\end{tabular}

${ }^{1}$ SPO RZL - Sektorowy Program Operacyjny Rozwój Zasobów Ludzkich dostępny w latach 2004-2006.

${ }^{2}$ PO KL - Program Operacyjny Kapitał Ludzki realizowany w latach 2007-2013.

${ }^{3}$ ZPORR - Zintegrowany Program Operacyjny Rozwoju Regionalnego.

${ }^{4}$ RPO WŁ - Regionalny Program Operacyjny Województwa Łódzkiego ze szczególnym uwzględnieniem osi V.3 Infrastruktura edukacyjna, projekty możliwe do realizacji w latach 2007-2013.

Źródło: opracowanie własne.

W okresie od 2006 do 2013 r. na terenie województwa łódzkiego zrealizowano szereg działań wspierających dzieci i młodzież, jak również kadrę pedagogiczną. Na podstawie sprawozdawczości Urzędu Marszałkowskiego w Łodzi oraz Krajowego Systemu Informatycznego na lata 2007-2013 gromadzących dane o podpisanych umowach o dofinansowanie projektów i podstawowej sprawozdawczości z ich realizacji stwierdzić można, że z powodzeniem zrealizowano także projekty mające na celu poprawę infrastruktury edukacyjnej. Projekty wspierające dzieci w wieku przedszkolnym realizowane były w województwie łódzkim głównie na terenie gmin wiejskich (71 ze 122 projektów), zgodnie z wytycznymi wskazującymi promowanie projektów w gminach o najniższym odsetku upowszechnienia edukacji przedszkolnej. W ramach projektów głównie tworzono nowe placówki przedszkolne w różnych formach zgodnie z prawodawstwem krajowym, 11 projektów wdrażano w gminach miejsko-wiejskich, a 24 na terenie gmin miejskich. Pozostałe 16 projektów dotyczyło działań promujących edukację przedszkolną. Wartość projektów przedszkolnych w gminach wiejskich stanowiła 49,2\% ogólnej wartości wszystkich 122 projektów.

Kolejnym rodzajem działań współfinansowanych z Europejskiego Funduszu Społecznego były projekty rozwojowe szkół prowadzących kształcenie ogólne, służące rozszerzeniu dotychczasowej oferty placówki poprzez dodatkowe zajęcia pozalekcyjne, w tym także dla 
dzieci i młodzieży niepełnosprawnej. Programy wyrównywania szans edukacyjnych służyły zwiększaniu dostępności do edukacji określonym grupom społecznym, np. mieszkańcom obszarów wiejskich poprzez działania ukierunkowane na zniesienie barier utrudniających możliwość korzystania z usług edukacyjnych. W ramach projektów możliwe było także wsparcie pedagogiczne, psychologiczne czy doradztwo zawodowe dla starszych uczniów. Łączna wartość dofinansowania 397 projektów w ramach działania 9.1.2. Programu Operacyjnego Kapitał Ludzki wyniosła ogółem ponad $161 \mathrm{mln}$ zł. Na terenach wiejskich realizowanych była większość z tych projektów - 186 (o wartości 55 mln zł), 131 projektów wdrażano w szkołach miejskich, a 51 na terenach gmin miejsko-wiejskich. Pozostałe projekty miały szerszy zasięg.

W ramach Programu Operacyjnego Kapitał Ludzki działania 9.4. Wysoko wykwalifikowane kadry systemu oświaty w latach 2009-2013 możliwe było także aplikowanie o środki finansujące doskonalenie nauczycieli i kadr systemu oświaty. W tym okresie do Urzędu Marszałkowskiego złożono 306 projektów, z czego tylko 65 otrzymało dofinansowanie. Najwięcej projektów - 27 zostało dofinansowanych w 2013 r. W ostatnich latach gminy miały także możliwość pozyskiwania środków na studia podyplomowe, kursy kwalifikacyjne i doskonalące dla nauczycieli. W ramach projektów współfinansowanych ze środków Europejskiego Funduszu Społecznego możliwe było pozyskanie funduszy na przekwalifikowanie części nauczycieli szkolnych w taki sposób, by mogli oni prowadzić drugi przedmiot lub zajęcia w ramach zatrudnienia w jednej szkole. Jest to szczególnie istotne w przypadku małych szkół wiejskich w sytuacji niżu demograficznego (Szczegółowy Opis Priorytetów... 2015, s. 301-305). Projekty z zakresu doskonalenia nauczycieli współfinansowane ze środków Europejskiego Funduszu Społecznego nie były tak powszechne, jak te skierowane do dzieci i młodzieży. Skala realizowanych działań nie była też tak duża i ogólnodostępna, podobnie jak zakontraktowane środki finansowe - na projekty przedszkolne w latach 2007-2014 dostępne było 129,8 mln zł, na projekty dla szkół ogólnych 199,2 $\mathrm{mln}$ zł, podczas gdy na działania związane z doskonaleniem kadry niespełna $40 \mathrm{mln}$ zł. Placówki oświatowe, a tym samym gminy będące ich organem prowadzącym, znacznie częściej decydowały się na realizację projektów skierowanych do dzieci i młodzieży, niż na projekty dla kadry pedagogicznej. W ostatnich dwóch latach (2012 i 2013) projekty doskonalenia kadry pedagogicznej i pracowników sektora oświaty były dostępne tylko dla osób zagrożonych zwolnieniem w ramach likwidacji placówek, związanej ze zmianami demograficznymi na danym terenie.

Gminy miały także możliwość aplikowania o środki wspierające rozwój infrastruktury edukacyjnej. W ramach Regionalnego Programu Operacyjnego Województwa Łódzkiego osi priorytetowej V.3. zrealizowano 16 projektów na rzecz infrastruktury sportowej, 15 projektów na doposażenie bazy dydaktycznej placówek oświatowych, 9 służyło budowie bądź przebudowie szkoły oraz 6 przystosowaniu budynku na cele przedszkola. Znaczna większość projektów (19) została zrealizowana na obszarach wiejskich województwa łódzkiego (wartość ogółem wynosiła 42,8 mln zł), 16 zrealizowano w gminach miejskich (wartość $56,8 \mathrm{mln}$ zł), a $11 \mathrm{w}$ gminach wiejsko-miejskich (31,3 mln zł).

W celu ukazania efektów oraz oddziaływania tych projektów w sferze edukacji w zakresie pięciu wcześniej wyodrębnionych obszarów nierówności (tab. 1) wybrano trzy gminy wiejskie: Drużbice z powiatu bełchatowskiego, Grabów z powiatu łęczyckiego i Kowiesy z powiatu skierniewickiego, które w sposób kompleksowy prowadziły działania służące pozyskiwaniu dodatkowych środków finansowych. Gmina Drużbice jest gminą typowo wiej- 
ską, z niewielkim udziałem sektora usług turystycznych, położoną na północno-wschodnim skraju powiatu bełchatowskiego. W jej skład wchodzi 47 miejscowości, w tym 31 sołectw. Jej atutem jest położenie przy trasie komunikacyjnej północ-południe / wschód-zachód - przez teren gminy przebiega droga ekspresowa S-8. W gminie funkcjonują dwie szkoły podstawowe (w Drużbicach i Wadlewie), w których realizowane jest także przygotowanie przedszkolne, jedno gimnazjum, jedna biblioteka publiczna, nie ma szkół ponadgimnazjalnych. Gmina Drużbice położona jest w środkowej części województwa, w pobliżu stolicy regionu. Pozostałe dwie gminy przyjęte do analizy położone są peryferyjnie na przeciwległych krańcach województwa łódzkiego. Zarówno gmina Grabów, jak i Kowiesy graniczą z sąsiednimi województwami - wielkopolskim i mazowieckim. Gmina Grabów położona w powiecie łęczyckim, w jego północno-wschodniej części, na skraju województwa łódzkiego, jest gminą typowo wiejską. Składa się z 65 miejscowości (40 sołectw). Na jej terenie funkcjonują cztery szkoły podstawowe (w Chorkach, Grabowie, Kadzidłowej i Starej Sobótce) oraz jedno gimnazjum w Grabowie. Gmina Kowiesy w powiecie skierniewickim, znajduje się na północno-zachodnim skraju województwa łódzkiego. Składa się z 29 miejscowości, w tym 24 sołectw. W gminie funkcjonują dwie szkoły podstawowe, placówki przedszkolne (w Kowiesach i Turowej Woli) oraz jedno gimnazjum w Jeruzalu (w którym także zlokalizowano punkt wychowania przedszkolnego). Na terenie gminy nie ma szkoły ponadgimnazjalnej. W gminie zlokalizowano świetlice wiejskie oraz bibliotekę gminną.

W wybranych do analizy gminach:

- realizowano w latach 2006-2013 projekty wyrównywania szans edukacyjnych dzieci i młodzieży,

- realizowano projekty na rzecz wspierania i rozwoju edukacji przedszkolnej, jak i projekty dla szkół podstawowych i gimnazjów,

- zrealizowano projekty z zakresu poprawy infrastruktury edukacyjnej.

Gminy wybrano z zestawień projektów zrealizowanych w województwie łódzkim, w ramach Sektorowego Programu Operacyjnego Rozwój Zasobów Ludzkich z lat 2004-2006 oraz Programu Operacyjnego Kapitał Ludzki z lat 2007-2013. Kryterium doboru była kompleksowość prowadzonych w gminach działań na rzecz sytuacji edukacyjnej obszaru, liczba zrealizowanych projektów dofinansowujących: edukację przedszkolną, zajęcia dodatkowe i wsparcie uczniów w szkołach podstawowych i gimnazjach, działania doskonalące dla nauczycieli i kadry szkół oraz liczba projektów inwestycyjnych w obydwu perspektywach czasowych oraz ich rodzaj - tj. wspierających możliwie najwięcej scharakteryzowanych powyżej obszarów nierówności edukacyjnych.

W tabeli 2 przedstawiono programy UE, w ramach których badane gminy realizowały projekty służące poprawie sytuacji edukacyjnej dzieci i młodzieży.

Tabela 2. Wybrane do analizy gminy oraz typy zrealizowanych projektów

\begin{tabular}{|l|c|c|c|c|c|c|}
\hline \multirow{2}{*}{ Gmina } & \multicolumn{3}{|c|}{ SPO RZL (2004-2006) } & \multicolumn{2}{c|}{ PO KL (2007-2010) } \\
\cline { 2 - 6 } & przedszkolne & szkolne & $\begin{array}{c}\text { doskonalenie } \\
\text { nauczycieli }\end{array}$ & przedszkolne & szkolne & $\begin{array}{c}\text { doskonalenie } \\
\text { nauczycieli }\end{array}$ \\
\hline \begin{tabular}{l|c|c|c|} 
Drużbice \\
Grabów
\end{tabular} & + & + & + & + & + \\
Kowiesy & + & + & + & + & + \\
\hline
\end{tabular}

Źródło: opracowanie własne 
Gminy realizowały także projekty inwestycyjne w ramach ZPORR i RPO Województwa Łódzkiego, których specyfiką jest możliwość przeznaczenia pozyskanych środków finansowych na określone rodzaje działań. Były to inwestycje w bazę dydaktyczną (m.in. budowa lub adaptacja budynku przedszkola lub szkoły, budowa szkolnej sali sportowej, jak również zakup niezbędnego wyposażenia obiektów).

\section{Nierówności w zakresie edukacji przedszkolnej i sposoby ich niwelowania w gminach Drużbice, Grabów i Kowiesy}

Prowadzenie edukacji przedszkolnej, która jest zadaniem własnym gminy, stanowi często znaczne obciążenie dla jej budżetuํ. Jednocześnie jest istotnym czynnikiem rozwoju kapitału ludzkiego gminy, przekłada się bowiem na dalsze szanse edukacyjne dzieci, umożliwia powrót matek na rynek pracy po przerwie związanej z urodzeniem dziecka, dlatego też część samorządów korzysta z możliwości dodatkowego dofinansowania tych działań ze środków zewnętrznych, głównie z Europejskiego Funduszu Społecznego. Dofinansowanie edukacji przedszkolnej wzbogaca ofertę zajęć dodatkowych i pozwala na doposażenie przedszkola. Dzięki realizacji oddolnych inicjatyw edukacyjnych na obszarach wiejskich wzrasta wskaźnik upowszechnienia edukacji przedszkolnej.

Projekty unijne mają jednakże określony czas trwania, a po ich zakończeniu część nowo utworzonych przedszkoli nie jest w stanie dalej realizować działań w takim samym zakresie. Ważna jest zatem partnerska współpraca placówki z gminą tak, aby po zakończeniu zewnętrznego finansowania przedszkole mogło dalej funkcjonować. Odwołując się do wspomnianych wcześniej obszarów nierówności w zakresie edukacji, dla każdego z nich wyodrębniono miary określające efektywność wdrażanych rozwiązań.

Dla obszaru 1/ Edukacja przedszkolna wyróżniono następujące miary:

a) liczba nowo utworzonych placówek wychowania przedszkolnego oraz liczba miejsc w przedszkolach,

b) typ utworzonej placówki przedszkolnej: przedszkole publiczne, przedszkole niepubliczne, punkt wychowania przedszkolnego, inna forma wychowania przedszkolnego (co ma znaczenie dla ilości godzin opieki nad dziećmi i realizowanej podstawy programowej kształcenia przedszkolnego ${ }^{2}$

c) liczba zatrudnionej kadry edukacyjnej o wyższych kwalifikacjach,

d) liczba i rodzaj zakupionych środków trwałych i pomocy dydaktycznych,

e) liczba, rodzaj i wartość przeprowadzonych ze środków unijnych inwestycji infrastrukturalnych.

\footnotetext{
1 Więcej m.in.: Herbst 2012a; Karczewska 2009; Lackowski 2008; Kowalik-Olubinska 2005; Guz 2005.

2 W prawie polskim na mocy obowiązujących przepisów możliwe są trzy formy edukacji przedszkolnej: jako placówki publicznej, niepublicznej bądź innej formy wychowania przedszkolnego. Ustawa z dn. 7 września 1991 r. o systemie oświaty (Dz. U. z 2004 r. Nr 256, poz. 2572 z późniejszymi zmianami) w art. 140 umożliwia prowadzenie placówki przedszkolnej samorządom gminnym, oraz innym osobom prawnym i osobom fizycznym. Muszą one spełnić określone w ustawie warunki: zapewnić wykwalifikowaną kadrę, realizować podstawę programową wychowania przedszkolnego zatwierdzoną przez MEN, oraz zapewnić warunki lokalowe określone odrębnymi przepisami. W znowelizowanej dn. 7 września 2007 r. ustawie o systemie oświaty (Dz. U. z 2007 r. nr 181, poz. 1292) wprowadza się możliwość prowadzenia innych form wychowania przedszkolnego - zespołów i punktów. Możliwe jest także zgodnie z art. 62.1 powołanie przez organ prowadzący zespołu szkolno-przedszkolnego składającego się z przedszkola i szkoły podstawowej, przedszkola i gimnazjum lub przedszkola, szkoły podstawowej i gimnazjum. Konieczna jest jednakże pozytywna opinia w sprawie powołania zespołu wydana przez kuratora oświaty
} 
Na podstawie danych ze stron internetowych trzech wspomnianych gmin wiejskich, a także danych dotyczących zrealizowanych projektów współfinansowanych ze środków UE określono wartości wskaźników dla obszaru 1/ Edukacja przedszkolna.

Tabela 3. Wybrane wskaźniki dotyczące zmian w edukacji przedszkolnej

\begin{tabular}{|c|c|c|c|c|}
\hline 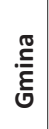 & $\begin{array}{l}\text { Liczba nowo utworzo- } \\
\text { nych placówek wycho- } \\
\text { wania przedszkolnego } \\
\text { / typ placówki }\end{array}$ & $\begin{array}{l}\text { Liczba zatrudnionej ka- } \\
\text { dry edukacyjnej o wyż- } \\
\text { szych kwalifikacjach }\end{array}$ & $\begin{array}{l}\text { Zakupione środki } \\
\text { trwałe i pomoce } \\
\text { dydaktyczne }\end{array}$ & $\begin{array}{l}\text { Przeprowadzone } \\
\text { ze środków unij- } \\
\text { nych inwestycje } \\
\text { infrastrukturalne }\end{array}$ \\
\hline 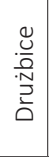 & $\begin{array}{l}2 \text { punkty przedszkolne } \\
\text { w Drużbicach i Wa- } \\
\text { dlewie } \\
\text { Obecnie: } 2 \text { PWP }^{1}\end{array}$ & $\begin{array}{l}\text { nauczycielka (mgr), po- } \\
\text { moc nauczycielki, woź- } \\
\text { na, zajęcia dodatkowe }\end{array}$ & $\begin{array}{l}\text { kąciki edukacyjne, } \\
\text { materiały do zajęć } \\
\text { z dziećmi, kompleksowe } \\
\text { doposażenie od VIII } \\
2008 \text { r. }\end{array}$ & $\begin{array}{l}\text { utworzenie placu } \\
\text { zabaw w Drużbicach } \\
\text { i w Wadlewie }\end{array}$ \\
\hline $\begin{array}{l}3 \\
\frac{0}{0} \\
\frac{0}{0} \\
\frac{0}{10}\end{array}$ & $\begin{array}{l}1 \text { punkt przedszkolny } \\
\text { w Grabowie, od } 2008 \text { r. } \\
\text { alternatywny ośrodek } \\
\text { przedszkolny w Starej } \\
\text { Sobotce, od } 2009 \text { r. } 2 \\
\text { oddziały w SP w Gra- } \\
\text { bowie, od } 2010 \text { r. } 1 \\
\text { oddział przedszkolny } \\
\text { w SP w Kadzidłowej } \\
\text { Obecnie: } 1 \text { PWP i } 3 \\
\text { oddziały w SP2 }\end{array}$ & $\begin{array}{l}\text { nauczycielka (mgr), } \\
\text { pomoc nauczycielki, } \\
\text { zajęcia dodatkowe }\end{array}$ & $\begin{array}{l}\text { utworzenie PWP w Gra- } \\
\text { bowie w XII } 2005 \text { r. }\end{array}$ & - \\
\hline 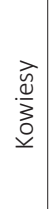 & $\begin{array}{l}2 \text { punkty przedszkolne } \\
\text { w Jeruzalu i Turowej } \\
\text { Woli, od } 2011 \text { r. oddział } \\
\text { przedszkolny w SP } \\
\text { w Kowiesach } \\
\text { Obecnie: } 2 \text { PWP, } 2 \\
\text { oddziały w SP }\end{array}$ & $\begin{array}{l}\text { nauczycielka (mgr), po- } \\
\text { moc, od } 2008 \text { r. nauczy- } \\
\text { cielka (mgr), pomoc } \\
\text { nauczycielki, woźna, } \\
\text { zajęcia dodatkowe }\end{array}$ & $\begin{array}{l}\text { utworzenie placówek } \\
\text { w gminie w XII } 2005 \text { r., } \\
\text { kompleksowe doposa- } \\
\text { żenie od VIII } 2008 \text { r. }\end{array}$ & $\begin{array}{l}\text { doposażenie placu } \\
\text { zabaw przy Zespole } \\
\text { Szkolno-Przedszkol- } \\
\text { nym w Turowej Woli } \\
\text { i w Jeruzalu }\end{array}$ \\
\hline
\end{tabular}

${ }^{1}$ PWP - punkt wychowania przedszkolnego

${ }^{2} \mathrm{SP}$ - oddział przedszkolny w szkole podstawowej

${ }^{3}$ zajęcia dodatkowe wiązały się z zatrudnieniem dodatkowej kadry specjalistycznej - logopedy, psychologa, nauczyciela realizującego zajęcia gimnastyki korekcyjnej, rytmiki oraz zajęcia z języka obcego.

Źródło: opracowanie własne

W latach 2006-2007 na terenie gmin Grabów i Kowiesy we współpracy z Towarzystwem Inicjatyw Europejskich utworzono po jednym punkcie wychowania przedszkolnego w Grabowie, Jeruzalu i Turowej Woli w ramach projektu Małe Przedszkole w Każdej Wsi (dofinansowanego z Sektorowego Programu Operacyjnego Rozwój Zasobów Ludzkich, Schemat 1.4 Zmniejszanie dysproporcji pomiędzy miastem a wsiq..). Z uwagi na duży popyt rodziców na te usługi po zakończeniu realizacji projektu konieczne było dalsze wsparcie finansowe tych punktów. Konsekwencją tych działań był projekt Małe Przedszkola w 5 wsiach województwa tódzkiego: Drużbice, Jeruzal, Turowa Wola, Wadlew, Zagórze (w ramach Programu Operacyjnego Kapitał Ludzki, Poddziałanie 9.1.1 zmniejszenie nierówności w stopniu upowszechnienia edukacji przedszkolnej), tworzony wspólnie z przedstawicielami Gminy Drużbice będącej organem prowadzącym dla dwóch punktów wychowania przedszkolnego w Drużbicach i Wadlewie oraz trzech organizacji pozarządowych prowadzących przedszkola w Jeruzalu (Stowarzyszenie Rozwoju Gminy Kowiesy), Turowej Woli (Stowarzyszenie Rozwoju Wsi Turowa Wola i Okolic) i Zagórzu (Stowarzyszenie Rozwoju Wsi Zagórze i Okolic). Projekt był realizowany od 1 sierpnia 2009 r. do 30 września 
2010 r. i zakładał wydłużenie funkcjonowania punktów wychowania przedszkolnego do 30 godzin tygodniowo oraz realizację zajęć dla dzieci z j. angielskiego, rytmiki, gimnastyki korekcyjnej i logopedii. W ramach projektu realizowane zostały także wyjazdy edukacyjne dzieci oraz zakupy niezbędnych pomocy dydaktycznych czy wsparcie infrastruktury otaczającej przedszkola. Głównym celem było zwiększenie uczestnictwa dzieci w edukacji przedszkolnej, a przede wszystkim uratowanie przed likwidacją zagrożonych punktów wychowania przedszkolnego. W ramach projektu do 5 przedszkoli uczęszczało 130 dzieci, realizując edukację przedszkolną w wymiarze podstawy programowej (Gabryelak 2011a, s. 91-93, 2011b, s. 248-251).

Wspieranie edukacji przedszkolnej na terenach wiejskich, niezależnie od form wychowania przedszkolnego, nawet w ograniczonym okresie przekłada się na niwelowanie nierówności w tym zakresie pomiędzy wsią i miastem. W wieku 3-5 lat zaczyna się, w zależności od kapitału ludzkiego i społecznego rodzin i bezpośredniego otoczenia, wzmacnianie mechanizmu dziedziczenia statusu społecznego ${ }^{3}$. Dzieci gorzej wykształconych rodziców rozpoczynają edukację średnio znacznie później niż dzieci rodziców o wyższym poziomie wykształcenia. Zatem edukacja przedszkolna przeciwdziała różnicowaniu szans edukacyjnych. Zróżnicowanie regionalne upowszechnienia edukacji przedszkolnej pokazuje, iż regiony o gospodarce silniej uzależnionej od rolnictwa, słabiej zurbanizowane, o niższym stopniu rozwoju społeczno-gospodarczego wykazują znacznie niższy stopień upowszechnienia edukacji przedszkolnej niż regiony uprzemysłowione i silnie zurbanizowane. Różnice międzyregionalne w zakresie upowszechnienia edukacji przedszkolnej są najbardziej widoczne na obszarach wiejskich, ale dzięki absorpcji funduszy unijnych stan ten ulega sukcesywnej poprawie (Hałabudra 2005, s. 89-91; Karczewska 2009, s.922; Kowalik-Olubińska 2005, s. 74-76).

\section{Programy wspierające rozwój uczniów w szkołach podstawowych i gimnazjach}

Różnice w poziomie osiągnięć szkolnych są widoczne stosunkowo wcześnie, bo już dzieci 5 letnie poddawane są ocenie dojrzałości i gotowości szkolnej. Dojrzałość szkolna dzieci jest określeniem stanu rozwoju dziecka, które staje przed nowymi wyzwaniami i ma sprostać nowym wymaganiom otoczenia. Dojrzałość, określana także mianem gotowości szkolnej, jest połączeniem dwóch procesów rozwojowych - dojrzewania i uczenia się. Ocenę tej gotowości wyznacza katalog cech związanych m.in. ze stopniem rozwoju emocjonalnego dziecka, poznawczego, motorycznego oraz jego umiejętności społeczne, które są powiązane z możliwościami sprostania wymaganiom szkolnym. Wspomaganie rozwoju dzieci jest szczególnie istotne w rodzinach o niższym statusie społecznym. Dzieci te posługują się kodem ograniczonym, komunikacja przebiega w sposób prosty, przy użyciu języka potocznego. Dzieci z rodzin o wyższym statusie społecznym na co dzień posługują się językiem bardziej uporządkowanym, używając logicznej argumentacji, bogatego słownictwa (Bourdieu i Passeron 2006, s. 75-84, 154). Ten sposób komunikacji jest preferowany w ramach systemu szkolnego, toteż dzieci z rodzin o niższym statusie społecznym często

\footnotetext{
${ }^{3}$ Dane statystyczne z ostatnich czterech lat szkolnych pokazują, że większość przedszkoli zlokalizowana była w miastach, podczas gdy inne formy wychowania przedszkolnego, oferujące opiekę nad dziećmi w ograniczonej formie i czasie, nadal dominują na obszarach wiejskich. Najczęściej edukacją przedszkolną objęte są dzieci starsze 5 i 6 letnie. Porównaj Gabryelak 2014, s. 44-52.
} 
nie rozumieją języka, którym posługuje się nauczyciel. Według socjologów edukacji jest to powód niepowodzeń szkolnych tych dzieci (Bourdieu i Passeron 2006; Bernstein 1961, s. 288-340). Taki stan rzeczy utrwala i reprodukuje istniejące w tych środowiskach przekonania o dziedziczności statusu, co z kolei powoduje zaniechanie dalszego kształcenia i brak wiary we własne możliwości. B. Bernstein mówi o utrwalaniu nierówności przez system szkolny, natomiast P. Bourdieu wprowadza pojęcie „habitusu klasowego”, z którego dziecko musiałoby wyjść po to, aby zmienić sposób postrzegania obiektywnej rzeczywistości i uwierzyć w możliwość rozwoju (Bourdieu i Passeron 2006, s. 75-85 i 155-161; Niezgoda 2011 s. 23-36, Bernstein 1961, s. 288-340). Jest to jednak trudne, uwzględniając rolę szkoły jako instytucji utrwalającej istniejący stan rzeczy, co przyczynia się do dalszego utrwalania stratyfikacji społecznej poprzez nierówne szanse edukacyjne (por. Kwieciński 2011). Ustalenia te potwierdzono także w badaniach Ch. Jencksa (1990, 1993), według którego najbardziej znaczącym czynnikiem wyjaśniającym zróżnicowanie osiągnięć szkolnych są czynniki rodzinne. W literaturze przedmiotu wyraźne są także głosy krytyczne dotyczące niskiej efektywności działań prowadzonych w ramach systemu szkolnego mających na celu monitorowanie osiągnięć szkolnych uczniów i wspomaganie ich rozwoju (Ansalone 2001, 2006). Ważne jest zatem, aby szczególnie w środowisku wiejskim działania prowadzone przez szkołę miały na celu wyrównanie tych dysproporcji. Realizacja zajęć wyrównawczych i wsparcia, w tym także doradztwa zawodowego, dzięki środkom unijnym pozwala na zmianę sytuacji edukacyjnej dzieci wiejskich. Prowadzenie zajęć pozalekcyjnych, w tym także współfinansowanych z funduszy unijnych, wymaga dodatkowego zaangażowania nauczycieli i dyrekcji. Najczęstszymi formami zajęć dodatkowych są: koła wiedzy, techniczne, artystyczne, sportowe, oraz krajoznawczo-turystyczne. Zajęcia dodatkowe w szkołach podstawowych są znacznie częstsze niż na poziomie edukacji gimnazjalnej, pełnią bowiem także funkcję zapełnienia czasu wolnego i są formą opieki nad najmłodszymi uczniami po zajęciach. Zajęcia pozalekcyjne realizowane są także w gimnazjach i szkołach ponadgimnazjalnych, ich celem jest wyrównywanie szans edukacyjnych młodzieży (por. Gabryelak 2014, s. 52-59).

Dla obszaru 2/ Zajęcia wyrównawcze i koła zainteresowań wyróżniono następujące miary:

a) rodzaje i liczba zajęć wyrównawczych, finansowanych ze środków unijnych,

b) efektywność przeprowadzonych zajęć - postęp w wynikach egzaminów uczniów objętych zajęciami dodatkowymi, wyrównującymi ich braki edukacyjne,

c) wskaźnik liczby promowanych do następnej klasy (dot. uczniów objętych dodatkowymi zajęciami),

d) rodzaje i liczba kół zainteresowań dla uczniów zdolnych.

W perspektywie budżetowej Unii Europejskiej na lata 2004-2006 wybrane do analizy gminy uczestniczyły w realizacji projektu Nowy Impuls. Projekty rozwojowe szkół wiejskich w województwie łódzkim. W drodze konkursu wyłoniono 58 szkół (z 47 gmin województwa łódzkiego), którym przyznano środki finansowe na realizację programów wyrównywania szans edukacyjnych uczniów. Projekt ten został dofinansowany z Sektorowego Programu Operacyjnego Rozwój Zasobów Ludzkich, Schemat 1.4 Zmniejszanie dysproporcji pomiędzy miastem a wsiq. Działania zaplanowane przez dyrektorów szkół wiejskich realizowano w szkołach w Wadlewie (gmina Drużbice), Grabowie i Starej Sobótce (gmina Grabów) oraz Jeruzalu i Turowej Woli (gmina Kowiesy). Projekt Nowy Impuls realizowany był w okresie 1.02.2007-31.03.2008 i zakładał opracowanie i wdrożenie projektów rozwo- 
jowych w szkołach wiejskich, zgodnych z lokalnym zapotrzebowaniem i ukierunkowanych na: wyrównywanie szans edukacyjnych, rozwijanie aspiracji edukacyjnych i społecznych uczniów pochodzących z obszarów wiejskich, umożliwienie uczniom zdobywanie dodatkowej wiedzy i umiejętności ułatwiających dalszą edukację i wybór ścieżki zawodowej. Projekty rozwojowe szkół miały za zadanie rozszerzać dotychczasową ofertę placówki, w tym proponować dodatkowe zajęcia pozalekcyjne.

W gminach Drużbice, Grabów i Kowiesy w projekcie Nowy Impuls brali udział uczniowie i uczennice szkół podstawowych. Jednym ze sposobów oceny efektów realizowanych działań może być weryfikacja wyników egzaminu szóstoklasisty - kończącego szkołę podstawową. W tabeli poniżej przedstawiono zestawienie wyników dla uczniów klas szóstych w szkołach podstawowych z trzech gmin wiejskich. W dwóch z nich - Drużbicach i Grabowie nastąpiło znaczne zmniejszenie liczby dzieci w roczniku, z 69 w 2008 r. do 47 w 2012 r. w przypadku Drużbic i z 84 do 53 w Grabowie. W natomiast Kowiesach odnotowano wzrost liczby szóstoklasistów.

Tabela 4. Wyniki sprawdzianu kończącego szkołę podstawową w latach 2008, 2010 i 2012

\begin{tabular}{|c|c|c|c|c|c|c|c|c|}
\hline Rok & Gmina & $\begin{array}{c}\text { Liczba } \\
\text { uczniów }\end{array}$ & $\begin{array}{l}\text { Czytanie } \\
\text { (10 pkt) }\end{array}$ & $\begin{array}{l}\text { Pisanie } \\
\text { (10 pkt) }\end{array}$ & $\begin{array}{l}\text { Rozumienie } \\
\text { (8 pkt) }\end{array}$ & $\begin{array}{c}\text { Korzystanie } \\
\text { z informacji } \\
\text { (4 pkt) }\end{array}$ & $\begin{array}{l}\text { Wykorzysta- } \\
\text { nie wiedzy } \\
\text { (8 pkt) }\end{array}$ & $\begin{array}{l}\text { Ogółem } \\
\text { (40 pkt) }\end{array}$ \\
\hline 2008 & \multirow{3}{*}{ Drużbice } & 69 & 7,71 & 6,84 & 5,35 & 2,46 & 4,68 & 27,04 \\
\hline 2010 & & 70 & 7,00 & 4,74 & 4,50 & 2,16 & 3,17 & 21,57 \\
\hline 2012 & & 47 & 5,72 & 5,81 & 3,77 & 2,55 & 2,94 & 20,79 \\
\hline 2008 & \multirow{3}{*}{ Grabów } & 84 & 7,74 & 4,88 & 5,51 & 2,05 & 4,06 & 24,24 \\
\hline 2010 & & 81 & 6,99 & 4,38 & 4,42 & 2,22 & 3,72 & 21,73 \\
\hline 2012 & & 53 & 5,43 & 5,62 & 3,85 & 2,89 & 3,77 & 21,57 \\
\hline 2008 & \multirow{3}{*}{ Kowiesy } & 28 & 8,81 & 5,71 & 6,07 & 5,24 & 4,87 & 26,89 \\
\hline 2010 & & 22 & 7,36 & 5,41 & 5,68 & 2,50 & 4,82 & 25,77 \\
\hline 2012 & & 31 & 5,58 & 6,23 & 3,29 & 2,42 & 2,81 & 20,32 \\
\hline
\end{tabular}

Źródło: opracowanie własne na podstawie danych Okręgowej Komisji Egzaminacyjnej w Łodzi.

Porównanie wyników egzaminu w poszczególnych latach wskazuje, że uczniowie osiągają słabe rezultaty. Na 40 możliwych do zdobycia punktów w 2008 r. średnia wyników w województwie łódzkim wynosiła 25,82 punktów, co oznacza ze uczniowie z Drużbic i Kowies zdali egzamin powyżej średniej wojewódzkiej, natomiast uczniowie z Grabowa poniżej średniej. W kolejnym analizowanym roku średnia wojewódzka spadła i wynosiła 24,41 punktów i lepiej egzamin zdali tylko uczniowie z Kowies, rezultat pozostałych był znacznie gorszy. W 2012 r. średnie wyniki egzaminu dla województwa wyniosły 22,90 punktów i w tym roku uczniowie i uczennice szkół z wszystkich trzech gmin zdali egzamin szóstoklasisty z rezultatem poniżej średniej. Można na tej podstawie wysnuć dwa wnioski, po pierwsze wyniki egzaminów w województwie łódzkim były w tym okresie coraz słabsze, po drugie również szóstoklasiści z terenu badanych gmin zdawali egzamin coraz gorzej. Trudno jednoznacznie określić, czy zaproponowane formy wsparcia w projekcie były nieefektywne, czy niewystarczające. Proponowane działania były pochodną potrzeb zgłaszanych przez dyrektorów szkół na podstawie przeprowadzanej przez nich diagnozy potrzeb uczniów i uczennic. 
W kolejnym okresie finansowania, w ramach środków europejskich dostępnych na lata 2007-2013 na terenie gminy Kowiesy zrealizowano projekt Dobry start - lepsza przyszłość dzieci i młodzieży w Gminie Kowiesy o wartości ogółem 454,5 tys. zł w tym z Europejskiego Funduszu Społecznego 386,4 tys. zł. Projekt realizowany był przez dwa lata w okresie od września 2009 do października 2011. Zaplanowane działania dla uczniów 3 szkół z terenu gminy (2 szkół podstawowych w Kowiesach i w Turowej Woli i gimnazjum w Jeruzalu) miały na celu realizację zajęć dodatkowych wspomagających rozwój uczniów i uczennic. Zrealizowano m.in.: zajęcia wyrównawcze z języka polskiego, matematyki, biologiczno-geograficzne, a także zajęcia specjalistyczne z logopedą, terapeutą pedagogicznym, jak również koła zainteresowań: medialne, lingwistyczne, badawcze i muzyczno-taneczne. Analizując wpływ projektu na wyniki egzaminu szóstoklasisty w tej gminie, można stwierdzić, że uczniowie i uczennice zdali egzamin kończący szkołę podstawową lepiej niż ich rówieśnicy z pozostałych gmin zarówno w roku 2010, jak i 2012 roku.

W gminie Drużbice w roku szkolnym 2012/2013 zrealizowano, współfinansowany ze środków Europejskiego Funduszu Społecznego w ramach PO Kapitał Ludzki, projekt zajęć dodatkowych pod nazwą Korzystaj z szans, rozwijaj zdolności, dołącz do najlepszych. Projekt realizowany był dla Gminy Drużbice, a skierowany dla uczniów i uczennic klas I-III Zespołu Szkolno-Przedszkolnego w Drużbicach oraz Szkoły Podstawowej im. M. Arciszewskiego w Wadlewie. W ramach projektu zrealizowano:

a) zajęcia dla dzieci ze specyficznymi trudnościami w czytaniu i pisaniu, w tym także zagrożonych ryzykiem dysleksji,

b) zajęcia dla dzieci z trudnościami w zdobywaniu umiejętności matematycznych,

c) zajęcia logopedyczne,

d) zajęcia socjoterapeutyczne i psychoedukacyjne dla dzieci z zaburzeniami komunikacji społecznej,

e) wsparcie pedagogiczno-psychologiczne.

Głównym celem zajęć było wspieranie indywidualnego rozwoju uczniów i uczennic tych szkół poprzez działania dostosowane do ich potrzeb, zniwelowanie trudności w uczeniu się, a także objęcie wsparciem pedagogiczno-psychologicznym. Wartość projektu ogółem wynosiła 67,5 tys. zł, w tym z EFS 57,4 tys. zł.

Kolejnym obszarem nierówności w zakresie edukacji, widocznym szczególnie na obszarach wiejskich, jest ograniczony dostęp do diagnozy deficytów i poradnictwa psychologiczno-pedagogicznego. Analiza danych statystycznych dotyczących liczebności gabinetów specjalistycznych, takich jak: pedagoga szkolnego, logopedy czy profilaktyki zdrowotnej i pomocy przedmedycznej pokazała, że znaczna część szkół ma możliwość diagnozowania uczniów na miejscu4 ${ }^{4}$ W gminach będących przedmiotem analizy nie występują poradnie psychologiczne. Sieć placówek edukacyjnych na analizowanym terenie składa się z ośmiu szkół podstawowych, w tym jednej szkoły niepublicznej prowadzonej przez Stowarzyszenie Rozwoju Wsi Turowa Wola i Okolic oraz trzech gimnazjów. W szkołach zwykle zatrudniony jest jeden pedagog szkolny, wyjątek stanowią SP w Starej Sobótce gmina Grabów i SP w Wadlewie gmina Drużbice zatrudniające zarówno logopedę, jak i pedagoga.

\footnotetext{
${ }^{4}$ Dla kompleksowej diagnozy ucznia i specjalistycznego wsparcia konieczne są poradnie psychologiczno-pedagogiczne. W województwie łódzkim wszystkie poradnie psychologiczno-pedagogiczne zlokalizowane są w miastach (na podstawie danych Oświata i Wychowanie GUS; por. Gabryelak 2014, s. 64).
} 
Dla obszaru 3/ Diagnoza i niwelowanie deficytów rozwojowych określono wskaźniki takie jak:

a) liczba uczniów objętych nauczaniem indywidualnym,

b) liczba uczniów objętych refundacją obiadu,

c) liczba uczniów objętych wsparciem psychologa,

d) liczba uczniów objętych dodatkowym wsparciem pedagoga.

Przykładem działań z zakresu wspomagania rozwoju dzieci są projekty indywidualizacji nauczania dla uczniów i uczennic najmłodszych z klas I-III szkół podstawowych. Każdy uczeń powinien być traktowany indywidualnie, z uwzględnieniem jego zasobów i potrzeb, które w efekcie przekładają się na jego osiągnięcia edukacyjne. Indywidualizacja nauczania jest sposobem pomocy psychologiczno-pedagogicznej, która polega na niwelowaniu niekorzystnych różnic między uczniami, przy jednoczesnym rozwijaniu cech pozytywnych. Dotyczy ona uczniów, u których zdiagnozowano specjalne potrzeby edukacyjne. Celem indywidualizacji pracy ucznia jest poprawa wyników uczenia się dzięki wykorzystaniu indywidualnych właściwości uczącego się i zwiększaniu jego indywidualnych możliwości. W okresie 2007-2013 możliwe było pozyskanie dodatkowych środków finansowych na działania z zakresu indywidualizacji, w ramach Poddziałania 9.1.2 Wyrównywanie szans edukacyjnych uczniów z grup o utrudnionym dostępie do edukacji oraz zmniejszanie różnic w jakości usług edukacyjnych. Oprócz wyłanianych w trybie konkursowym programów rozwojowych szkół i placówek oświatowych prowadzących kształcenie ogólne, przewidziano realizację programów indywidualizacji procesu nauczania i wychowania uczniów klas I-III jako projektów systemowych dostępnych dla gmin. Projekty takie zrealizowane zostały w Grabowie - wartość 127, 6 tys. zł, w tym z EFS 108,5 tys. zł w okresie od września 2012 do lipca 2013 oraz w Kowiesach - wartość projektu 30 tys. zł, w tym z EFS 25,5 tys. zł, okres realizacji: wrzesień 2012-czerwiec 2013.

Projekty skierowane do uczniów i uczennic klas I-III w analizowanych gminach pozwoliły na usprawnienie procesu edukacyjnego dzieci najmłodszych. Ich dodatkowe wsparcie psychologiczne i pedagogiczne może w znaczący sposób przyczynić się do zwiększenia możliwości edukacyjnych w kolejnych etapach kształcenia. Pozwala także na łagodniejsze przejście z etapu opieki przedszkolnej do nauki w szkole podstawowej. Praca z uczniem dostosowana do jego możliwości pozwala także na wczesne wspomaganie rozwoju, w ramach ścisłej współpracy z rodzicami dzieci objętych wsparciem. Szczególnie ważne jest oferowane w projektach wsparcie specjalistyczne, trudno dostępne dla najmłodszych z uwagi na oddalenie od ośrodków prowadzących diagnostykę i wspomaganie rozwoju poradni psychologiczno-pedagogicznych.

\section{Projekty doskonalenia nauczycieli na terenie wybranych gmin}

Doświadczenie i kwalifikacje nauczycieli są gwarancją jakości nauczania i wpływają bezpośrednio na proces kształcenia. Jednym z ważniejszych aspektów pracy nauczycieli jest ich awans zawodowy. W Karcie Nauczyciela zapisano czterostopniową skalę awansu zawodowego. Pierwszym jest stopień stażysty, po roku pracy i po uzyskaniu pozytywnej oceny z egzaminu można uzyskać stopień nauczyciela kontraktowego. Po kolejnych trzech latach i egzaminie kwalifikacyjnym nauczyciel uzyskuje mianowanie. Najwyższym stopniem nauczycielskiego awansu jest uzyskanie stopnia nauczyciela dyplomowanego. 
Aby poprawiać poziom prowadzonych przez siebie szkół, gminy i powiaty powinny nie tylko monitorować sytuację kadry nauczycielskiej, ale także sprzyjać stałemu podwyższaniu jej kwalifikacji ${ }^{5}$. Najważniejszymi narzędziami służącymi temu celowi są różne formy dokształcania i doskonalenia nauczycieli. Są one finansowane z jednoprocentowego odpisu z osobowego funduszu płac nauczycieli.

Dla obszaru 4/ Doskonalenie nauczycieli i kadry przyjęto wskaźniki:

a) liczba projektów unijnych przeznaczonych na podnoszenie kwalifikacji,

b) liczba nauczycieli podejmujących doskonalenie zawodowe - kursy i studia podyplomowe.

W ramach wyłonionych do dofinasowania projektów sześć dostępnych było dla nauczycieli zatrudnionych w szkołach na terenie gmin Drużbice i Kowiesy. Dostępne są dane szczegółowe dotyczące tylko jednej z analizowanych gmin, Grabowa, pozostałe dwie na swoich stronach internetowych nie umieściły informacji dotyczących udziału nauczycieli w szkoleniach czy kursach doskonalących.

Tabela 5. Projekty doskonalenia nauczycieli w badanych gminach

\begin{tabular}{|c|l|l|}
\hline \multicolumn{1}{|c|}{ Gmina } & $\begin{array}{c}\text { Liczba projektów unijnych przeznaczonych } \\
\text { na podnoszenie kwalifikacji }\end{array}$ & $\begin{array}{l}\text { Liczba nauczycieli podejmujących doskonale- } \\
\text { nie zawodowe - kursy i studia podyplomowe }\end{array}$ \\
\hline Drużbice & $\begin{array}{l}\text { 3 projekty doskonalenia nauczycieli dla osób } \\
\text { z terenu powiatu bełchatowskiego }\end{array}$ & brak danych \\
\hline Grabów & $\begin{array}{l}1 \text { projekt dla osób z powiatu łęczyckiego, } \\
\text { nauczyciele z Grabowa uczestniczyli w 3 } \\
\text { projektach }\end{array}$ & $\begin{array}{l}26 \text { nauczycieli z gimnazjum w Grabowie w za- } \\
\text { kresie ICT, zajęć technicznych, j. angielskiego }\end{array}$ \\
\hline Kowiesy & $\begin{array}{l}\text { 3 projekty dla nauczycieli z terenu powiatu } \\
\text { skierniewickiego }\end{array}$ & brak danych \\
\hline
\end{tabular}

Źródło: opracowanie własne

Zajęcia w ramach projektu Nowe kwalifikacje szansq na stabilizację - studia podyplomowe i kursy kwalifikacyjne dla nauczycieli z terenu Powiatu Bełchatowskiego odbywały się od września 2010 do lipca 2011 r. (355 godz. - 3 semestry, w systemie sobotnio-niedzielnym) w Poradni Psychologiczno-Pedagogicznej w Bełchatowie i prowadzone były przez wyspecjalizowanych wykładowców. Dla nauczycieli zaplanowano zajęcia w blokach tematycznych: logopedyczny, diagnostyczny, terapeutyczny, rozwijania umiejętności psychologicznych, edukacyjny, resocjalizacyjny, psychoterapeutyczny, profilaktyki, wypalenia zawodowe oraz seminarium dyplomowe. Nauczyciele z powiatu bełchatowskiego brali także udział w projekcie Nowe kwalifikacje szansq na stabilizacje - studia podyplomowe i kursy kwalifikacyjne dla nauczycieli z terenu Powiatu Betchatowskiego realizowanym w roku szkolnym 2010/2011.

W gminie Grabów 14 nauczycieli z Gimnazjum w Grabowie oraz Szkoły Podstawowej w Sobótce Starej uczestniczyła w kursie języka angielskiego w projekcie Nowoczesny nauczyciel - nowoczesna szkoła. Zajęcia realizowano od października 2013 r. do marca

5 Prawie 47\% nauczycieli w roku szkolnym 2006/2007 posiadało stopień nauczyciela mianowanego, ponad $32 \%$ to nauczyciele dyplomowani, natomiast nauczyciele kontraktowi i stażyści to odpowiednio 15,1\% i 5,6\% wszystkich nauczycieli. W roku szkolnym 2011/2012 pracowało 479,5 tys. nauczycieli we wszystkich typach szkół i placówek wychowania przedszkolnego, co stanowiło spadek liczby nauczycieli o 1,4\% w stosunku do roku poprzedniego. Obecnie sektor publiczny zatrudnia 90,7\% wszystkich nauczycieli, z czego najwięcej w placówkach gminnych (65,6\% wszystkich zatrudnionych). W sektorze prywatnym jest 9,3\% wszystkich etatów nauczycielskich (w roku poprzednim 8,4\%). 
2014 r. na terenie gimnazjum w Grabowie. W roku szkolnym 2013/2014 w projekcie Wykwalifikowani nauczyciele i pracownicy pedagogiczni publicznych szkół i placówek oświatowych gwarantem jakości nauczania w szkołach województwa łódzkiego brało udział 12 nauczycieli Gimnazjum im. Jana Kochanowskiego w Grabowie.

\section{Inwestycje w infrastrukturę edukacyjną i społeczną wsi}

Ostatnią z analizowanych barier w rozwoju edukacji na obszarach wiejskich jest niewystarczająca ilość środków finansowych przeznaczonych na oświatę. Fundusze przekazywane w ramach subwencji oświatowej w przypadku małych szkół są niewystarczające. Należy pamiętać, iż funkcje szkoły wiejskiej są rozleglejsze niż szkoły miejskiej. Jest ona nie tylko miejscem kształcenia uczniów, ale często prężnym i jedynym ośrodkiem kultury, miejscem spotkań lokalnych liderów, kreujących lokalną aktywność. Ponadto wiejskie szkoły prowadzą nauczanie w mniejszych grupach, tym samym oferują lepsze warunki kształcenia. Z danych GUS wynika, iż wiejska klasa liczy średnio 15 uczniów, podczas gdy w miastach 22. Natomiast dotacja w ramach subwencji oświatowej jest pochodną liczby uczniów w szkole. Dlatego sytuacja finansowa wielu gmin nie pozwala na realizację dużych inwestycji infrastrukturalnych w organizowanych na swoim terenie placówkach oświatowych (Herbst 2012a, s. 98-103, 173-220).

Pomocne w tym zakresie są fundusze europejskie, powalające na przeprowadzenie dużych inwestycji przy stosunkowo niewielkim własnym wkładzie finansowym. W każdym z województw, w ramach Programów Regionalnych, działania Infrastruktura edukacyjna, gminy miały możliwość pozyskania znacznych środków na adaptację budynków na cele oświatowe, na doposażenie bazy dydaktycznej czy budowę infrastruktury sportowej.

Dla obszaru 5/ Poprawa infrastruktury edukacyjnej określono takie miary jej efektywności, jak:

a) liczba przeprowadzonych inwestycji,

b) rodzaj inwestycji:

- budowa obiektów,

- przebudowa i adaptacja,

- doposażenie bazy dydaktycznej.

W tabeli 6. zebrano informacje dotyczące prowadzonych w gminach inwestycji z zakresu poprawy infrastruktury edukacyjnej, współfinansowanych z różnych środków zewnętrznych.

Na proces kształcenia i możliwości dalszego rozwoju uczniów znaczący wpływ ma infrastruktura edukacyjna i wyposażenie szkoły. Wiejska szkoła podstawowa o uboższej infrastrukturze (z czterokrotnie mniejszą w stosunku do szkół miejskich liczbą pracowni przedmiotowych, dwukrotnie mniejszą liczbą sal gimnastycznych, węższą ofertą nauczania języków obcych) pełni znacznie ważniejszą rolę w społeczności lokalnej niż szkoła w mieście. Stanowi często jedyne (jakże istotne) zaplecze kulturowe miejscowości. Szkoła wiejska jest często jednym z niewielu miejsc, w których młodzież mogłaby się spotykać, spędzać razem czas wolny, poznawać i rozwijać własne zainteresowania. Dlatego tak istotne jest, aby była miejscem dostępnym i otwartym na inicjatywy młodzieży. W analizowanym okresie najwięcej inwestycji prowadzonych było w gminie Drużbice, a realizowane działania obejmowały kompleksowo wsparcie i rozbudowę infrastruktury sportowej, przebudowy 
i remonty budynków oświatowych, w tym także z przeznaczeniem dla dzieci niepełnosprawnych i najmłodszych w wieku od 3 do 5 lat. Wszystkie trzy gminy starają się pozyskiwać środki na działania z zakresu edukacji ekologicznej, tworzenia ścieżek dydaktycznych czy doposażenia pracowni ze środków Wojewódzkiego Funduszu Ochrony Środowiska i Gospodarki Wodnej w Łodzi. Często realizowanymi działaniami inwestycyjnymi jest także tworzenie przyszkolnych placów zabaw dla dzieci. Gminy starają się realizować inwestycje przy wykorzystaniu jak największej puli środków zewnętrznych, jednakże przy większości inwestycji konieczny jest udział wkładu własnego z budżetu gminy. Przy dużych wieloletnich projektach o znacznej wartości stanowi to utrudnienie dla gminy, ze względu na konieczność zaplanowania środków o znacznej wartości w wieloletnim planie inwestycyjnym.

Tabela 6. Typy inwestycji w zakresie infrastruktury edukacyjnej w wybranych gminach

\begin{tabular}{|c|c|c|c|c|}
\hline \multirow[b]{2}{*}{ Gmina } & \multicolumn{4}{|c|}{ Rodzaj inwestycji } \\
\hline & $\begin{array}{l}\text { infrastruktura } \\
\text { sportowa }\end{array}$ & $\begin{array}{l}\text { doposażenie bazy } \\
\text { dydaktycznej }\end{array}$ & $\begin{array}{l}\text { budowa / przebudo- } \\
\text { wa szkoły }\end{array}$ & $\begin{array}{l}\text { przystosowanie } \\
\text { na cele przedszkola }\end{array}$ \\
\hline Drużbice & $\begin{array}{l}\text { wielofunkcyjna } \\
\text { hala sportowa } \\
\text { w Drużbicach }\end{array}$ & $\begin{array}{l}\text { doposażenie pracow- } \\
\text { ni, głównie środki } \\
\text { WFOŚiGW }\end{array}$ & $\begin{array}{l}\text { remonty, dostosowa- } \\
\text { nie do potrzeb osób } \\
\text { niepełnosprawnych }\end{array}$ & $\begin{array}{l}\text { utworzenie placówki, } \\
\text { oczyszczalnia ścieków, } \\
\text { place zabaw }\end{array}$ \\
\hline Grabów & & $\begin{array}{l}\text { doposażenie pra- } \\
\text { cowni, głównie środki } \\
\text { WFOŚiGW }\end{array}$ & & utworzenie placówki \\
\hline Kowiesy & & $\begin{array}{l}\text { doposażenie pracow- } \\
\text { ni, głównie środki } \\
\text { WFOŚiGW }\end{array}$ & $\begin{array}{l}\text { dostosowanie dla po- } \\
\text { trzeb niepełnospraw- } \\
\text { nych, plac zabaw dla } \\
\text { klas I-III }\end{array}$ & $\begin{array}{l}\text { utworzenie placówki, } \\
\text { place zabaw }\end{array}$ \\
\hline
\end{tabular}

Źródło: opracowanie własne

\section{Zakończenie}

Fundusze Unii Europejskiej mogą mieć istotny wpływ na działania z zakresu edukacji realizowane na terenie gmin wiejskich. Wykorzystanie dodatkowych środków jest szczególnie ważne w obszarze edukacji przedszkolnej. Gminy wiejskie rzadko decydują się bowiem na prowadzenie przedszkola bez pozyskania dofinansowania, gdyż związane jest to ze znacznym obciążeniem ich budżetu. Pozyskanie środków z Europejskiego Funduszu Społecznego na prowadzenie tego typu placówki, jak w przypadku analizowanych gmin, nawet jeśli konieczne jest zapewnienie dalszej ciągłości projektu po jego zakończeniu, pozwala na znaczną oszczędność w budżecie gminy. Zwiększenie na terenach wiejskich liczby dzieci objętych edukacją przedszkolną, nawet w ramach innych form wychowania przedszkolnego, w ograniczonym zakresie czasowym, powoduje pozytywne zmiany w niwelowaniu nierówności. Dzięki środkom EFS w gminach Drużbice, Grabów i Kowiesy powstały placówki przedszkolne, prowadzone zarówno przez gminę, jak i te niepubliczne zarządzane przez organizacje pozarządowe we współpracy z gminą.

Oferowane w szkołach zajęcia dodatkowe, koła zainteresowań, zajęcia pozwalające lepiej przygotować się do egzaminów kończących dane etapy kształcenia, wymagają

\footnotetext{
${ }^{6}$ Środki na edukację ekologiczną dostępne w ramach dofinansowania z Wojewódzkiego Funduszu Ochrony Środowiska i Gospodarki Wodnej w Łodzi.
} 
od gmin wygospodarowania dodatkowych nakładów finansowych na wynagrodzenia dla nauczycieli, dlatego też korzystne jest pozyskiwanie środków zewnętrznych na ten cel. Szkoły wiejskie, z uwagi na ograniczony budżet gminy, nie oferują tylu rodzajów zajęć co w miastach. Istotną rolę odgrywa także status społeczno-ekonomiczny rodziców. Wielu z nich nie może pozwolić na sfinansowanie korepetycji czy uczestnictwa w zajęciach dydaktycznych, wyrównawczych czy artystycznych. Trudno na podstawie zgromadzonego materiału z terenu gmin Drużbice, Grabów i Kowiesy jednoznacznie ocenić efekty zrealizowanych projektów z zakresu Poddziałania 9.1.2 Wyrównywanie szans edukacyjnych uczniów z grup o utrudnionym dostępie do edukacji oraz zmniejszanie różnic w jakości usług edukacyjnych. Analiza wyników egzaminów szóstoklasisty nie daje bowiem jednoznacznego obrazu. Niezaprzeczalne jest, że wyniki egzaminu kończącego szkołę podstawową w województwie łódzkim są z roku na rok coraz słabsze, natomiast nie można jednoznacznie stwierdzić, czy wsparcie oferowane uczniom w ramach projektów jest niewystarczające, a jego formy nieefektywne. Jednym z elementów wdrażania tego typu projektów jest także planowanie programu rozwoju szkoły i konsekwentna realizacja kompleksowych działań. Projekt rozwoju szkoły może bowiem pośrednio zwiększyć konkurencyjność gminy poprzez aktywizację zawodową nauczycieli, lepsze kwalifikacje uczniów i rozbudzenie postaw obywatelskich skłaniających do podejmowania różnorodnych działań na terenach gminy. Niewątpliwie istotnym elementem wspierania edukacji na obszarach wiejskich są programy indywidualizacji wdrażane dla najmłodszych uczniów. Wsparcie zaproponowane we wszystkich trzech gminach dla dzieci w klasach I-III może w znaczący sposób przyczynić się, podobnie jak edukacja przedszkolna, do zwiększenia ich szans na kolejnych etapach edukacji.

W opinii autorek zastanawiająca jest mała aktywność kadry pedagogicznej w projektach z zakresu doskonalenia, studiów podyplomowych i kursów specjalistycznych. Zawód nauczyciela wiąże się z koniecznością ciągłego doskonalenia i aktualizacji wiedzy i umiejętności. Doskonalenie zawodowe nauczyciela jest „obowiązkowe”, ponieważ podlega ocenie związanej z ewentualnym awansem zawodowym. Jak pokazują dane zgromadzone w Systemie Informacji Oświatowej, nauczyciele w związku z powyższym preferują krótsze formy, a w samym roku szkolnym 2008/2009 w różnych formach doskonalenia uczestniczyło faktycznie 12\% nauczycieli (Fedorowicz i Sitek 2011, s. 192-193, por. także Fedorowicz i Wojciuk 2012, s. 21-22, 208). Kluczowe znaczenie dla lepszych efektów procesu edukacyjnego mają kwalifikacje nauczycieli, umiejętność wykorzystania potencjału pracy w mało licznej grupie i wspieranie w ten sposób uczniów o specjalnych potrzebach oraz właściwe wykorzystanie infrastruktury (por. Rice 2002).

Działania w analizowanych gminach w zakresie pozyskiwania środków inwestycyjnych wskazują na ich dużą aktywność i świadomość możliwości. Dofinansowanie dużych inwestycji na terenie gminy wiąże się jednak z koniecznością opracowania dokumentacji specjalistycznej, która zwykle wykonywana jest przez firmy zewnętrzne i opłacana ze środków własnych gminy. Jednym z czynników mogących mieć wpływ na decyzje gminy o wdrażaniu projektów inwestycyjnych jest także konieczność wniesienia wkładu własnego. Projekty infrastruktury edukacyjnej często nie są traktowane priorytetowo jak inne inwestycje, np.: kanalizacja, oczyszczalnie, drogi czy termomodernizacja obiektów użyteczności publicznej. Inwestycje edukacyjne są więc jednymi z kilku rodzajów projektów inwestycyjnych, na które władze gminy muszą zabezpieczyć część środków. Dlatego też w analizowanych gminach pozyskiwane są również mniejsze środki wspierające bazę 
dydaktyczną, które wymagają mniejszych bądź żadnych nakładów finansowych ze środków własnych.

Wyrównywanie szans edukacyjnych dzieci zamieszkujących obszary wiejskie jest jednym z priorytetów Unii Europejskiej. Diagnoza sytuacji uczniów z obszarów wiejskich pokazała, że podstawowymi barierami, tak na poziomie województwa łódzkiego, jak i dla całego kraju są: ograniczenia ekonomiczne, infrastrukturalne i poziom wykształcenia mieszkańców wsi, a co za tym idzie mniejsza konkurencyjność na rynku pracy.

Dzięki realizacji polityki spójności poprzez absorpcję funduszy unijnych możliwe jest wpływanie na poprawę jakości życia mieszkańców i wyrównanie dysproporcji pomiędzy miastem a wsią. Efektywność realizacji programów dofinansowanych z funduszy unijnych zależy od szeroko zakrojonej współpracy pomiędzy władzami rządowymi, samorządem lokalnym, organizacjami pozarządowymi, rodzicami, nauczycielami, wolontariuszami i biznesem. Fundusze unijne pozwalają dofinansować programy lokalne, w tym także oddolne inicjatywy w zakresie edukacji na terenach wiejskich województwa łódzkiego. Sieci kontaktów oraz wsparcia, utworzone przy okazji tworzenia projektów tego typu, stanowią wartość dodaną wszystkich działań. Mogą być czynnikiem zwiększania współpracy społeczności wiejskich. Projekt rozwoju szkoły może pośrednio zwiększyć konkurencyjność gminy poprzez lepsze kwalifikacje uczniów i rozbudzenie postaw przedsiębiorczych, skłaniających do podejmowania różnorodnej działalności na jej terenach. Konieczne jest zatem dalsze inwestowanie przede wszystkim w rozwój kapitału ludzkiego. Młodzież z obszarów wiejskich stanowi duży potencjał rozwojowy dla swoich gmin, konieczne jest jednak wykorzystanie i wspieranie ich aspiracji edukacyjnych, przejawiających się w dużej aktywności w zajęciach dodatkowych rozwijających wiedzę formalną i umiejętności. Warto, aby władze lokalne i liderzy stworzyli młodym szanse rozwoju ich aktywności społecznej i zawodowej, w tym także przedsiębiorczości, działania te wymagają szczególnej uwagi i rozwiązań systemowych.

\section{Literatura}

Ansalone G., 2009, Exploring unequal achievement in the schools. The social construction of failure, Lexington Books, Lanham, Plymouth.

Bernstein B., 1961, Social Class and Linguistic Development: A Theory of Social Learning, [w:] A. H. Halsey i in. (red.), Education, Economy, and Society, New York, s. 288-314.

Bourdieu P., Passeron J. C., 2006, Reprodukcja, PWN, Warszawa.

Coleman J., et al., 1966, Equality of educational opportunity, D.C.U.S. Government, Washington.

Dolata R., 2010, Międzyszkolne zróżnicowanie wyników nauczania w szkołach podstawowych i gimnazjach, [w:] J. Łukasik, I. Nowosad, M. J. Szymański (red.), Edukacja. Równość czy jakość?, Wydawnictwo Adam Marszałek, Toruń.

Dolata R., 2008, Szkoła - segregacje - nierówności, Wydawnictwa Uniwersytetu Warszawskiego, Warszawa.

Federowicz M, Wojciuk A. (red.), 2012, Raport o stanie edukacji 2011, Kontynuacja przemian, Instytut Badań Edukacyjnych, Warszawa

Gabryelak E., 2014, Obszary nierówności w zakresie edukacji i próby ich niwelowania przy wykorzystaniu funduszy unijnych na przykładzie województwa łódzkiego, [w:] E. Psyk-Piotrowska (red.), Nowe mechanizmy rozwoju obszarów wiejskich, Wydawnictwo Uniwersytetu Łódzkiego, Łódź, s. 41-92. 
Gabryelak E., 2011a, Szanse edukacyjne i emocjonalna gotowość szkolna dzieci 6-letnich (na przykładzie projektów "Małe Przedszkole w Każdej Wsi” $i$ „Małe Przedszkola w 5 wsiach województwa tódzkiego..." ), Kwartalnik Nauczanie Początkowe, 1, Kielce, s. 88-93.

Gabryelak E., 2011b, Wyrównywanie szans edukacyjnych dzieci przedszkolnych w regionie tódzkim (na podstawie współdziałania samorzqdu terytorialnego i organizacji pozarządowej przy udziale środków unijnych), [w:] A. Organiściak-Krzyszkowska i B. Balcerzak-Paradowska (red.), Społeczno-Ekonomiczne Problemy Regionów, Uniwersytet Warmińsko-Mazurski w Olsztynie, Instytut Pracy i Spraw Socjalnych w Warszawie, s. 235-253.

Gorlach K., 2003, Młode pokolenie wsi III Rzeczypospolitej: aspiracje życiowe w przeddzień integracji z Uniq Europejskq, Instytut Spraw Publicznych, Warszawa.

Guz S. (red.), 2005, Rozwój i edukacja dziecka. Szanse i zagrożenia, Wydawnictwo UMCS, Lublin.

Hałabudra E., 2005, Szanse edukacyjne dziecka we współczesnym świecie - dostępność oświaty na poczq̨tkowych jej szczeblach, [w:] S. Guz (red.), Rozwój i edukacja dziecka szanse i zagrożenia, UMCS, Lublin, s.87-92.

Herczyński J., 2012, Wyzwania oświatowe stojqce przed samorzqdami, [w:] A. Levitas (red.), Strategie oświatowe, Biblioteczka Oświaty Samorządowej, Wydawnictwo ICM, Uniwersytet Warszawski, Warszawa, s. 14-39.

Herbst M., (red.), 2012a, Finansowanie oświaty, Biblioteczka Oświaty Samorządowej, Wydawnictwo ICM, Uniwersytet Warszawski, Warszawa.

Herbst M., 2012b, Edukacja jako czynnik i wynik rozwoju regionalnego: doświadczenia Polski w perspektywie międzynarodowej, Scholar, Warszawa.

Jencks Ch., 1993, Rethinking social Policy: race, poverty, and the underclass, Harper Perennial, New York.

Jencks Ch., Mayer, S. E.,1990, The social consequences of growing up in poor neighbor-hood, [w:] L. Lynn, M. G. H. Geary (red.), Inner-city poverty in the United States, National Academy Press, Washington, DC.

Karczewska J., 2009, Placówki wychowania przedszkolnego, ich organizacja i funkcjonowanie, [w:] E. Zyzik (red.), Wybrane zagadnienia z pedagogiki przedszkolnej, Uniwersytet Humanistyczno-Przyrodniczy Jana Kochanowskiego, Kielce, s. 9-22.

Kowalik-Olubińska M., 2005, Zwiększenie szans edukacyjnych dzieci sześcioletnich, [w:] S. Guz (red.), Rozwój i edukacja dziecka szanse i zagrożenia, UMCS, Lublin, s. 73-86.

Kwiecińska-Zdrenka M., 2004, Aktywni czy bezradni wobec własnej przyszłości?; młodzież wiejska na tle ogółu młodzieży, Wydawnictwo Uniwersytetu Mikołaja Kopernika, Toruń.

Kwieciński Z., 2011, Cztery i pót: preliminaria - liminaria - varia, Wydawnictwo Naukowe Dolnośląskiej Szkoły Wyższej, Wrocław.

Lackowski J., 2008, Decentralizacja zarzqdzania polskim systemem oświatowym a społeczne nierówności edukacyjne, Wydawnictwo Uniwersytetu Jagiellońskiego, Kraków.

Narodowa Strategia Spójności (Narodowe Strategiczne Ramy Odniesienia 2007-2013), Ministerstwo Rozwoju Regionalnego, Warszawa dostępny w Internecie https://www.funduszeeuropejskie.2007-2013.gov.pl/.../NSRO_maj2007.pdf

Niezgoda M. (red.), 2011, Społeczne skutki zmiany oświatowej w Polsce, Wydawnictwo Uniwersytetu Jagiellońskiego, Kraków.

Oświata i wychowanie w roku szkolnym 2006/2007, GUS, 2007.

Oświata i wychowanie w roku szkolnym 2007/2008, GUS, 2008.

Oświata i wychowanie w roku szkolnym 2008/2009, GUS, 2009.

Oświata i wychowanie w roku szkolnym 2009/2010, GUS, 2010. 
Oświata i wychowanie w roku szkolnym 2010/2011, GUS, 2011.

Oświata i wychowanie w roku szkolnym 2011/2012, GUS, 2012.

Oświata i wychowanie w roku szkolnym 2012/2013, GUS, 2013.

Płaszczyńska S., Różne formy edukacji przedszkolnej na wsi w świetle prawa oświatowego, Federacja Inicjatyw Oświatowych, dostępny w Internecie <www.mmp.fio.org.pl>, FIO, Warszawa.

Program Operacyjny KapitałLudzki, Ministerstwo Infrastruktury i Rozwoju, Warszawa 14 stycznia 2015 r. dostępny w Internecie http://www.kapitalludzki.gov.pl/dokumenty/dokumenty-programowe/ program-kapital-ludzki/

Program Rozwoju Edukacji na Obszarach Wiejskich na lata 2008-2013, Ministerstwo Edukacji Narodowej, Internet, (dostęp 15.10.2014), dostępny: www.men.gov.pl, MEN, Warszawa

Program Rozwoju Obszarów Wiejskich 2007-2013, Ministerstwo Rolnictwa i Rozwoju Wsi, wrzesień 2015, dostępny w Internecie http://www.minrol.gov.pl/Wsparcie-rolnictwa-i-rybolowstwa/ PROW-2007-2013/Dokumenty-analizy-raporty

Rice M. J., 2009, Effect Size in Psychiatric Evidence-Based Practice Care, Journal of the American Psychiatric Nurses Association, 15, 138-142.

Strategia Rozwoju Edukacji na Obszarach Wiejskich na lata 2007-2013, Ministerstwo Edukacji Narodowej, Internet, (dostęp 15.10.2014), dostępny: www.men.gov.pl, MEN, Warszawa

Szafraniec K. (red.), 2008, Młodość i oświata za burta przemian: z prac Sekcji Socjologii Edukacji i Młodzieży, PTS, Wydawnictwo Adam Marszałek, Warszawa.

Szafraniec K., 2011, Młodzi 2011, Kancelaria Prezesa Rady Ministrów, Warszawa.

Szafraniec K., 2012, Szanse życiowe wiejskiej młodzieży, [w:] J. Wilkin, J. Nużyńska (red.), Polska wieś 2012. Raport o stanie wsi, Wydawnictwo Naukowe SCHOLAR, Warszawa, s. 203-218.

Szczegółowy Opis Priorytetów Programu Operacyjnego Kapitał Ludzki 2007-2013, Ministerstwo Infrastruktury i Rozwoju, Warszawa 8 września 2015 r. dostępny w Internecie http://www.kapitalludzki.gov.pl/dokumenty/dokumenty-programowe/szczegolowy-opis-priorytetow/

Ustawa z dnia 7 września 1991 r. o systemie oświaty (Dz.U. z 2004 nr 256, poz. 2572 ze zm.) isap. sejm.gov.pl

\section{Summary}

Projects promoting transformation of education in rural areas, ranging from pre-school through the implementation of programs in schools, support new and adequate skills of teaching staff as well as investments in educational infrastructure are possible due to European Funds. Thanks to the activity of the commune and/or local leaders in rural areas it is possible to obtain EU funds to implement comprehensive measures to support existing educational institutions and establish new ones, retrofitting teaching base, including development of sports infrastructure, change in qualifications of teaching staff as well as investments in education infrastructure. The article presents an analysis of activities carried out using EU funds in three selected communes in the Łódzkie Voivodship, in the selected three rural communes: Drużbice, Grabów and Kowiesy, in the period 2006-2013 with respect to statistics on different implemented projects for the corresponding period and selected areas of education inequality. 
http://rcin.org.pl 